\title{
PERUBAHAN GARIS PANTAI DESA BENTENAN KECAMATAN PUSOMAEN, MINAHASA TENGGARA
}

\author{
Esry Tommy Opa ${ }^{1}$
}

\begin{abstract}
Bentenan village, located on the East coast of Minahasa peninsula and surrounded by gently sloping hills, has a shoreline of $1.3 \mathrm{~km}$. The shape of the shoreline is curved facing Bentenan Island. It is observed that coastline had been gradually retreating. Research and data collection on the coastline has been conducted in November 2008. As many as 85 points have been plotted using GPS, rectified with LPI maps and compared with a couple of old maps, i.e., Peta Dishidros Lembar 3341992 and Peta Laut No. 62 1985. Shoreline of Bentenan village shown to be retreated 165 meters in average towards the mainland from 1985 to 2008 (23 years), averaging a decrease of 7.17 meters. This indicates that the shore of Bentenan undergoes a process of erosion/ abrasion which causes changes in shoreline backwards towards the land, also called beach retreat.
\end{abstract}

Keywords: Bentenan, shorelines, Abrasion, beach retreat, geomorphology.

\begin{abstract}
ABSTRAK
Desa Bentenan memiliki panjang garis pantai sekitar $1,3 \mathrm{~km}$, terletak di pantai Timur semenanjung Minahasa yang bertopografi landai dan dikelilingi oleh perbukitan. Bentuk pantainya melekuk ke dalam dan di bagian depannya terdapat pulau Bentenan. Teramati bahwa bentuk pantai ini makin mundur dari tahun ke tahun. Observasi dan pengukuran dilakukan pada bulan November 2008, sebanyak 85 titik telah dipetakan dengan menggunakan GPS dengan koreksi dari peta LPI dan hasilnya dibandingkan dengan beberapa peta terdahulu yaitu Peta Dishidros lembar 334 tahun 1992, Peta Laut No 62 tahun 1985. Perbandingannya menunjukan garis pantai desa Bentenan mengalami perubahan rata-rata sebesar $165 \mathrm{~m}$ mundur ke arah daratan dalam selang waktu 1985-2008 (23 tahun). Dalam periode tersebut setiap tahun daerah ini mengalami kemunduran garis pantai rata-rata $7,17 \mathrm{~m}$.
\end{abstract}

Kata kunci: Bentenan, Garis pantai, Abrasi, Pantai mundur, geomorfologi.

${ }^{1}$ Staf pengajar Fakultas Perikanan dan Ilmu Kelautan Universitas Sam Ratulangi, Manado, Sulawesi Utara

\section{PENDAHULUAN}

Daerah pesisir khususnya kawasan pantai dan sekitarnya menyimpan potensi kekayaan alam yang besar dan merupakan daerah yang paling banyak dimanfaatkan.

Kawasan pantai sering dimanfaatkan sebagai daerah pemukiman, tempat pariwisata, daerah budidaya, daerah reklamasi dan sarana umum lainnya seperti jalan.

Desa Bentenan merupakan salah satu desa pesisir yang terletak di Pantai Timur semenanjung Minahasa, menyimpan begitu banyak potensi alam dan budaya. Menurut catatan yang ada, Desa Bentenan mulai dihuni secara bertahap sejak tahun 1600-an oleh suku pengembara laut Bajo dari Bolaang Mongondow, Ternate, dan Tidore, serta kelompok suku Minahasa dari Ratahan dan Langowan yang datang kemudian pada tahun 1800-an.

Pantai di Desa Bentenan bertopografi landai yang dikelilingi oleh perbukitan. Umumnya garis pantai Desa Bentenan merupakan garis pantai yang melekuk ke dalam, dan di bagian depannya terdapat Pulau Bentenan (Gambar 1).

Informasi yang didapat dari anggota masyarakat Desa Bentenan, puluhan tahun lalu garis pantai berada kurang lebih 80 meter ke arah laut dibandingkan garis pantai sekarang.

Berdasarkan uraian di atas maka perubahan garis pantai perlu ditelaah seca- 
ra cermat untuk mengetahui berubahan bentuk lahan di suatu daerah.

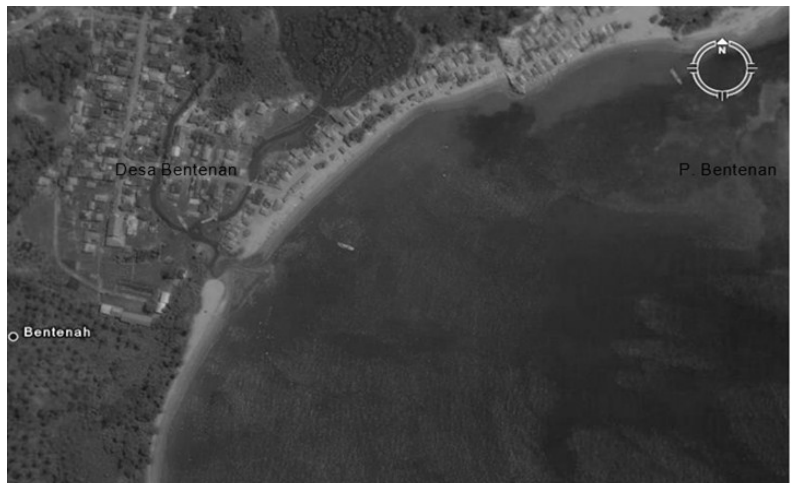

Gambar 1. Lokasi Penelitian, Desa Bentena (foto satelit Gogle 2007)

Pantai merupakan daerah datar atau bisa bergelombang dengan perbedaan ketinggian tidak lebih dari 200 meter, yang dibentuk oleh endapan pantai dan sungai yang bersifat lepas, dicirikan dengan adanya bagian yang kering (daratan) dan basah (rawa). Pantai adalah suatu daerah yang meluas dari titik terendah air laut pada saat surut hingga ke arah daratan sampai mencapai batas efektif dari gelombang (Gambar 2). Garis pantai adalah garis pertemuan antara air laut dengan daratan yang kedudukannya berubah-ubah sesuai dengan kedudukan pada saat pasang-surut, pengaruh gelombang dan arus laut (Sutikno, 1993).

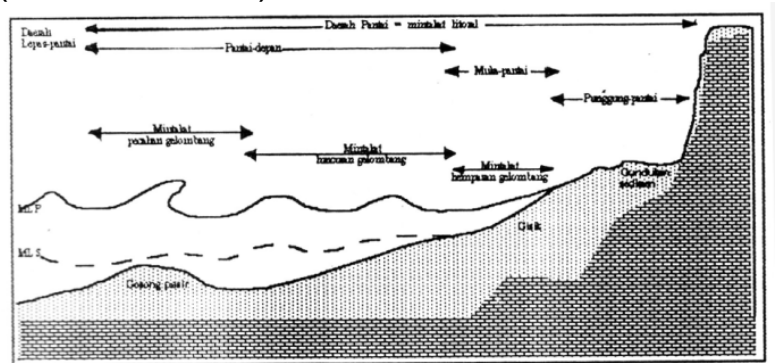

Gambar 2. Sketsa Umum Daerah Pantai (Sutikno, 1993).

Lingkungan pantai merupakan daerah yang selalu mengalami perubahan. Perubahan lingkungan pantai dapat terjadi secara lambat hingga cepat, tergantung pada imbang daya antara topografi, batuan dan sifat-sifatnya dengan gelombang, pasut, dan angin. Perubahan garis pantai ditunjukkan oleh perubahan kedudukannya, tidak saja ditentukan oleh suatu faktor tunggal tapi oleh sejumlah faktor beserta interaksinya. Secara garis besar proses geomorfologi yang bekerja pada mintakat pantai dapat dibedakan menjadi proses destruksional dan konstruksional. Proses destruksional adalah proses yang cenderung merubah/ merusak bentuk lahan yang ada sebelumnya, sedangkan proses konstruksional adalah proses yang membentuk lahan baru (Sutikno, 1993).

Faktor-faktor utama yang merupakan kontributor perubahan garis pantai adalah:

\section{a. Faktor Hidro-Oseanografi}

Perubahan pantai terjadi apabila proses geomorfologi yang terjadi pada segmen pantai melebihi proses yang biasa terjadi. Perubahan proses geomorfologi merupakan akibat dari sejumlah parameter oseanografi yang berperan seperti gelombang, arus, dan pasut.

\section{Gelombang}

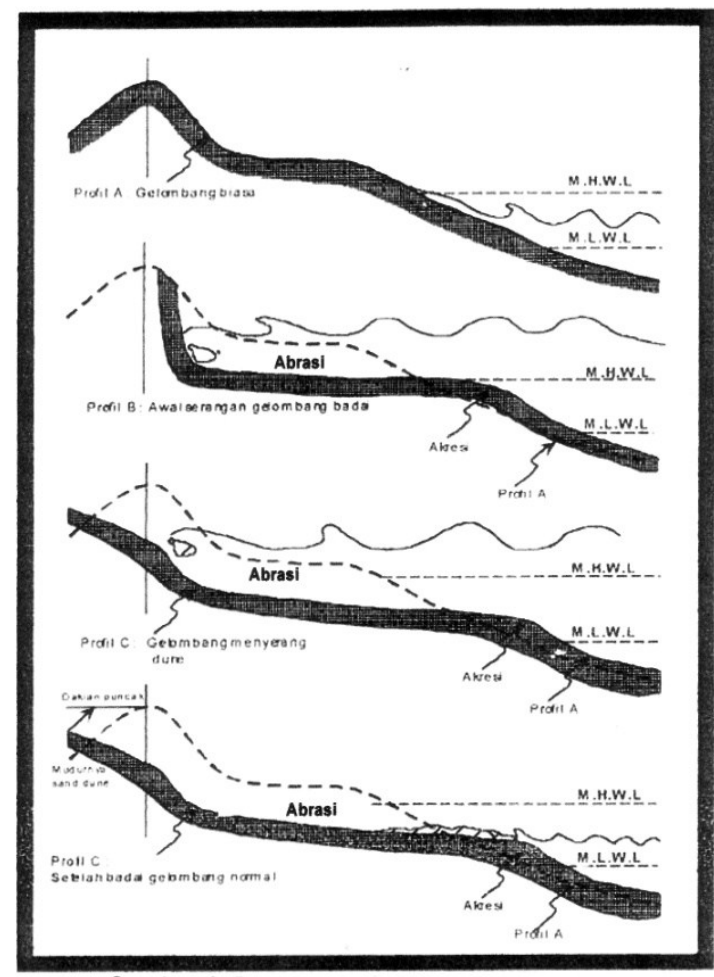

Gambar 3. Proses Abrasi di Pantai (Triatmodjo, 1999).

Gelombang terjadi melalui proses pergerakan massa air yang dibentuk secara umum oleh hembusan angin secara tegak lurus terhadap garis pantai (Open University, 1993). Gelombang merambat ke segala arah membawa energi yang kemudian dilepaskannya ke pantai dalam bentuk hempasan ombak. Dahuri, et al. (2001) menyatakan bahwa gelombang yang pecah di daerah pantai merupakan salah satu penyebab utama terjadinya proses erosi dan 
sedimentasi di pantai. Pada saat gelombang mendekati pantai, gelombang mulai bergesek dengan dasar laut dan menyebabkan pecahnya gelombang di tepi pantai. Hal ini mengakibatkan terjadinya turbulensi yang kemudian membawa material dari dasar pantai atau terkikisnya bukit-bukit pasir (dunes). Gelombang yang terjadi di daerah gelombang pecah mengandung energi yang besar dan sangat berperan dalam pembentukan morfologi pantai, seperti menyeret sedimen (umumnya pasir dan kerikil) yang ada di dasar laut untuk ditampung dalam bentuk gosong pasir.

Pada pantai yang terjadi pecahan gelombang, massa air bergerak menuju pantai dan apabila setelah gelombang pecah banyak massa udara yang terperangkap maka akan mempunyai daya erosi yang besar. Efek kombinasi antara tekanan udara dan benturan massa air mempunyai kapasitas untuk mengikis batuan dan memindahkan material lepas yang disebut dengan proses penggalian (Sutikno, 1993). Pecahan gelombang juga mampu mengangkut atau menggerakan material lepas ke pantai sehingga terjadi proses abrasi terhadap material di garis pantai (Gambar 3) (Triatmodjo, 1999).

\section{Arus}

Hutabarat dan Evans (1985) menyatakan, arus merupakan salah satu faktor yang berperan dalam pengangkutan sedimen di daerah pantai. Arus merupakan gerakan mengalir suatu massa air yang dapat disebabkan oleh adanya radiasi matahari, tiupan angin, pasut air laut, hempasan gelombang, dan adanya perbedaan densitas air laut (Nontji 2002).

Arus yang berfungsi sebagai media transpor sedimen dan sebagai agen pengerosi yaitu arus yang dipengaruhi oleh hempasan gelombang. Gelombang yang datang menuju pantai dapat menimbulkan arus pantai (nearshore current) yang berpengaruh terhadap proses sedimentasi/ abrasi di pantai. Arus pantai ini ditentukan terutama oleh besarnya sudut yang dibentuk antara gelombang yang datang dengan garis pantai (Pethick, 1997).

Jika gelombang datang membentuk sudut, maka akan terbentuk arus susur pantai (longshore current) yaitu arus yang bergerak sejajar dengan garis pantai akibat perbedaan tekanan hidrostatik.

\section{Pasut}

Menurut Nontji (2002) pasut adalah gerakan naik turunnya muka laut secara berirama yang disebabkan oleh gaya tarik bulan dan matahari. Posisi kedudukan buIan dan matahari dalam orbit selalu berubah relatif terhadap bumi. Apabila bulan dan matahari berada kurang lebih pada satu garis lurus dengan bumi, seperti pada saat bulan baru atau pada saat bulan purnama, maka gaya tarik keduanya akan saling memperkuat. Dalam keadaan demikian terjadilah pasut purnama (spring tide) dengan tinggi air yang luar biasa, melebihi tinggi pasang yang umum. Sebaliknya, surutnyapun sangat rendah, hingga lokasilokasi tertentu yang landai bisa menjadi kering sampai jauh ke laut. Tetapi jika bulan dan matahari membentuk sudut sikusiku terhadap bumi maka gaya tarik keduanya akan saling meniadakan. Akibatnya, perbedaan tinggi air antara pasang dan surut hanya kecil saja, dan keadaan ini dikenal sebagai pasut perbani (neep tide).

Perpindahan massa air laut dari satu lokasi menuju lokasi lain pada waktu pasut, menyebabkan timbulnya arus pasut. Biasanya arahnya kurang lebih bolak-balik, yaitu jika muka air bergerak naik maka arus mengalir masuk, sedangkan pada saat muka air bergerak turun maka arus mengalir ke luar. Arus pasut ini berperan terhadap proses-proses di pantai seperti penyebaran sedimen dan abrasi pantai. Pasang naik akan menyebarkan sedimen ke dekat pantai, sedangkan bila surut akan menyebabkan majunya sedimentasi ke arah laut lepas. Arus pasut umumnya tidak terlalu kuat sehingga tidak dapat mengangkut sedimen yang berukuran besar.

\section{b. Faktor Anthropogenik}

Proses anthropogenik adalah proses geomorfologi yang diakibatkan oleh aktivitas manusia. Aktivitas manusia di pantai dapat mengganggu kestabilan lingkungan pantai. Gangguan terhadap lingkungan pantai dapat dibedakan menjadi gangguan yang disengaja dan gangguan yang tidak disengaja. Gangguan yang disengaja bersifat protektif terhadap garis pantai dan ling- 
kungan pantai, misalnya dengan membangun jetti, groin, pemecah gelombang atau reklamasi pantai. Aktivitas manusia yang tidak disengaja menimbulkan gangguan negatif terhadap garis pantai dan lingkungan pantai, misalnya pembabatan hutan bakau untuk dikonversi sebagai tambak (Sutikno 1993).

Klasifikasi pantai diperlukan untuk menggolongkan pantai, sehingga tiap pantai memiliki ciri utama yang dapat membedakan antara pantai yang satu dengan pantai yang lain. Salah satu klasifikasi pantai adalah klasifikasi menurut Valentin (1952) dalam Sutikno,1993 yaitu perkembangan garis pantai maju dan perkembangan garis pantai mundur. Perubahan yang dihasilkan pada penampilan garis pantai, menurut Pethick (1997), tidak hanya berlangsung dalam kurun waktu yang relatif pendek (jam atau menit). Pantai maju dapat disebabkan oleh pengangkatan pantai atau prodegradasi oleh deposisi, sedangkan pantai mundur disebabkan oleh pantai tenggelam atau retrogradasi oleh erosi.

\section{METODE PENELITIAN}

Pelaksanaan observasi dan pengambilan data dilakukan pada bulan November 2008 di daerah garis pantai desa Bentenan, Kecamatan Pusomaen, Kabupaten Minahasa Tenggara. Metode yang digunakan adalah pengamatan dan pengukuran lapangan dengan menggunakan GPS (Global Positioning System) Garmin e-Trex 30 sebanyak 85 titik di sepanjang garis pantai desa Bentenan direkam koordinat geografisnya.

Koordinat geografis sebelum diolah dikoreksi untuk menghindari kesalahan pembacaan GPS di lapangan. Dalam melakukan koreksi peta digunakan beberapa simbol yang tertera pada peta yang diketahui di sekitar lokasi pengukuran, selanjutnya koordinat koreksi di lapangan serta peta LPI, akan dikurangi atau ditambah untuk memperoleh posisi koordinat terkoreksi. Peta garis pantai yang dihasilkan dibandingkan dengan cara tumpang tindih dengan peta Dishidros Tahun 1992 lembar 344 (Kapal Pemeta BORNEO tahun 19071908 dan Peta Laut no.62 edisi 1985) untuk mengukur serta menghitung perubahan yang terjadi.

\section{HASIL DAN PEMBAHASAN}

Desa Bentenan merupakan Desa pantai yang berhadapan langsung dengan Laut Maluku yang berada pada posisi geografis $1^{\circ} 00^{\prime} 2,0^{\prime \prime}-1^{\circ} 00^{\prime} 27,8^{\prime \prime} \mathrm{LU}$ dan $124^{\circ} 53^{\prime}$ $32,1^{\prime \prime}-124^{\circ} 53^{\prime} 54,0$ "BT dan memiliki panjang garis pantai sekitar $1,3 \mathrm{~km}$. Dalam pengambilan data, diambil titik pertama yang menjadi acuan untuk memulai pengukuran, kemudian menyusuri garis pantai sampai pada titik terakhir yang ditentukan. Jumlah titik yang diambil dalam penelitian ini sebanyak 85 titik. Titik pertama yang ditentukan pada penelitian ini yaitu pada posisi geografis $1^{\circ} 00^{\prime} 2,0^{\prime \prime}-1^{\circ} 00^{\prime} 27,8^{\prime \prime}$ LU dan $124^{\circ}$ 53 '32, 1"'-12453'54,0" BT.

Berdasarkan hasil pengamatan garis pantai di Desa Bentenan mengalami kemunduran ke arah darat. Dari hasil pembandingan Peta Dishidros tahun 1992 dan Peta Hasil Pengukuran di lapangan terlihat jelas perubahannya, sebelumnya garis pantai berada jauh ke arah laut tapi saat ini garis pantai menjorok ke arah daratan. Dari hasil pengamatan dan analisis peta dapat dihitung besar perubahan yang tejadi, perubahan garis pantai desa Bentenan mengalami kemunduran garis pantai bervariasi, terbesar \pm 300 meter dan terkecil \pm 30 meter dalam selang waktu tahun 1985-2008 (23 tahun), jika dirata-ratakan maka besar kemunduran garis pantai desa Bentenan sebesar \pm 165 meter, yang diperkirakan tiap tahunnya mengalami pengurangan daratan sebesar $\pm 7,17$ meter. Hal ini menunjukkan bahwa daerah ini mengalami proses erosi/ abrasi yang menyebabkan perubahan bentuk lahan garis pantai mundur ke arah darat atau disebut juga pantai mundur.

Erosi pantai akan menurunkan nilai guna bahkan menghilangkan potensi yang dimiliki suatu kawasan pantai. Erosi pantai terjadi apabila di suatu pantai yang ditinjau mengalami kehilangan/pengurangan sedimen; artinya sedimen yang terangkut lebih besar daripada yang diendapkan (Triatmodjo 1999). Terjadinya erosi pantai disebabkan oleh tiga faktor pengerosi yaitu gelombang, arus dan pasang surut (Sunarto, 1991). 
Gelombang merupakan tenaga erosif yang penting di pantai, tetapi efeknya bervariasi mengikuti besarnya energi gelombang dan karakteristiknya serta sifat batuan yang terkena gelombang (Sutikno 1993). Dalam hal ini gelombang berfungsi untuk membongkar material yang ada di bibir pantai dan oleh arus akan dipindahkan ke tempat lain.

Kombinasi tinggi gelombang yang besar dan periode gelombang yang pendek menyebabkan erosi pantai. Tiga faktor yang paling berkontribusi pada erosi pantai yaitu: tinggi gelombang, lamanya gelombang (durasi), dan keterjalan gelombang.

Arus merupakan media transpor sedimen dan sebagai agen pengerosi. Jika energi arus bekerja pada sedimen maka sedimen akan berpindah tempat mengikuti arah arus. Proses pemindahan sedimen oleh arus ini menurut Duxbury \& Duxbury (1993), berawal dari pembongkaran sedimen yang diakibatkan oleh gelombang pecah dari daerah pantai, selanjutnya sedimen yang tersuspensi di kolom air akan dipindahkan ke laut.

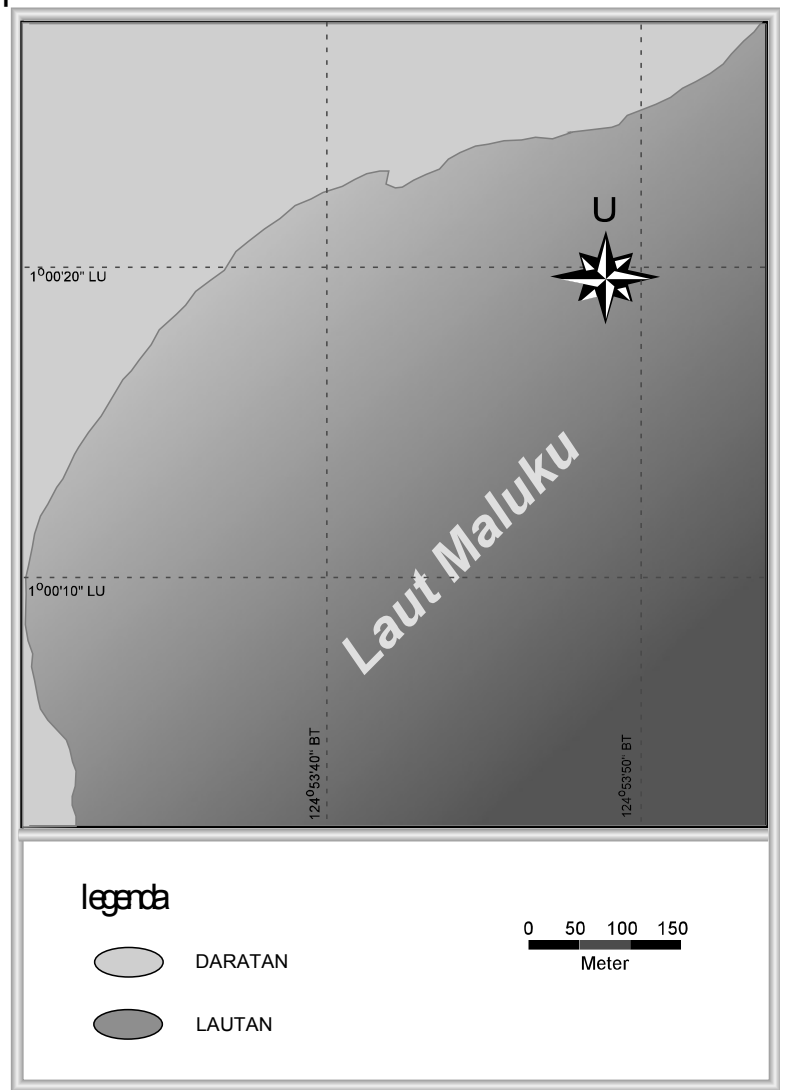

Gambar 4. Peta Hasil Pengukuran

Watung (2004), mengungkapkan bahwa kisaran kecepatan arus di perairan sekitar Desa Bentenan antara 0,04-0,20 knot, dengan rata-rata kecepatan 0,09 knot dan membentuk sudut datang gelombang antara $5^{\circ}-30^{\circ}$, dengan arah dominan Barat Daya. Hal ini mengidentifikasikan terjadinya arus susur pantai dan memungkinkan di daerah ini mengalami erosi/abrasi pantai.

Berdasarkan Peta Karakterisktik Pantai terbitan Pusat Pengembangan Geologi Kelautan (PPGK 1996), daerah pantai desa Bentenan dan sekitarnya teridentifikasi memiliki karakteristik pantai bertipe VII. Kawasan pantai tipe ini menggambarkan keadaan geologinya berasal dari batuan vulkanik yang terdiri dari breksi, lava, tufa dan tersusun oleh batu gamping dengan relief pantainya tinggi dan karakteristik dari garis pantainya bertebing terjal, terumbu koral, pasir, kerikil, kerakal, bongkah dan bakau.

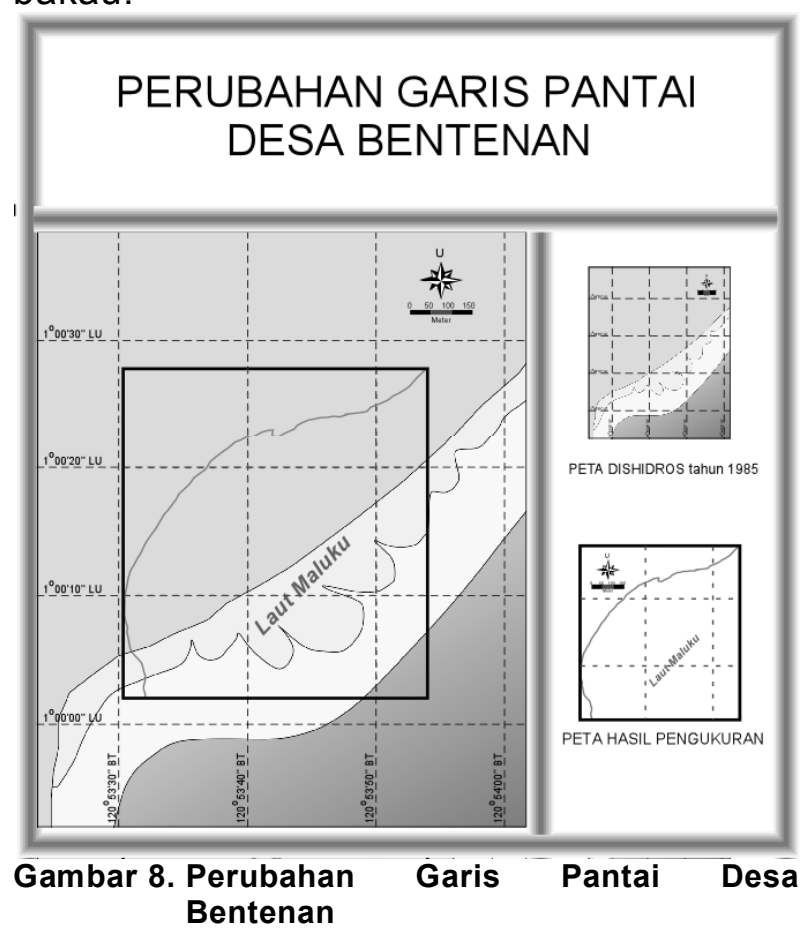

\section{KESIMPULAN}

Berdasarkan hasil Pengukuran dan pemetaan yang dilaksanakan di Desa Bentenan, Kecamatan Pusomaen, Kabupaten Minahasa Tenggara dapat diketahui bahwa daerah ini merupakan salah satu dari desa pantai yang mengalami perubahan garis pantai berupa pemunduran garis pantai ke arah darat atau mengalami erosi/abrasi yang disebabkan oleh aksi laut berupa arus susur pantai dan gelombang. Perubahan ini 
mungkin terjadi akibat aktivitas laut seperti badai dan gelombang tinggi serta pola arus yang dapat mempercepat proses abrasi dan transpor sedimen dari daerah ini. Garis Pantai Desa Bentenan mengalami perubahan rata-rata sebesar $165 \mathrm{~m}$ mundur ke arah daratan dalam selang waktu 1985-2008 (23 tahun), jika dihitung rata-rata dalam setiap tahun daerah ini mengalami pengurangan daratan 7,17 meter.

\section{DAFTAR PUSTAKA}

Duxbury A.B. \& A.C. Duxbury, 1993, Fundamental of Ocanography. Wm. C. Brown Publisher. Washington. 291 Pages.

Hutabarat S. \& S.M. Evans, 1985. Pengantar Oseanografi. UI-Press. Jakarta. 159 hal.

Nontji, 1987, Laut Nusantara, Penerbit Djambatan, Jakarta, 368 hal.

Open University, 1993, Waves, Tides, and Shallow Water Processes. Pergamon Press. 368 pages.

Peta Dishidros lembar 334 tahun 1992.

Peta Laut No 62 tahun 1985.
Pethick, 1997, An Introduction to Coastal Geomorphology. Edward Arnold a Division of Holder and Stougthon, London. 260 Pages.

PPGK, 1996. Survei Tematik Kelautan Terintegrasi, Inventarisasi Sumberdaya Geologi dan Geofisik Kelautan di Wilayah MCMA Manado dan Sekitarnya, Sulawesi Utara. Pusat Pengembangan Geologi Kelautan. Bandung.

Sunarto, 1991. Goemorfologi Pantai. Pusat Antar Univeritas. UGM. Joyakarta. 52 Hal.

Sutikno, 1993. Karakteristik Bentuk dan Geologi Pantai di Indonesia. DIKLAT PU WIL III. Dirjen Pengairan Pepartemen PU. Bentuk dan Geologi Pantai di Indonesia. DIKLAT PU WIL III. Dirjen Pengairan Pepartemen PU. Yogyakarta. 51 Hal.

Triatmodjo, B. 1999. Teknik Pantai. Beta Offset. Yogyakarta. 370 Hal.

Watung, 2004. SKRIPSI FPIK Unsrat Manado, PS IImu Kelautan. 